\title{
NOTES
}

\section{Thermal Polymerization of Alkali and Alkaline Earth 2-Bromo-n-butyrates in the Solid State}

\author{
Yasuyuki TaKaO,* Yoshio Kasashima, ${ }^{*}$ Mari InOKI, ${ }^{*}$ Fumihiko AkUtSU, ${ }^{*, \dagger}$ \\ Kiyoshi NarUCHI,* and Yoshiaki YamaGUCHI** \\ *Department of Applied Chemistry, Faculty of Engineering, Chiba University, \\ Yayoi-cho 1-33, Inage-ku, Chiba-shi 263, Japan \\ ** Musashino Chemical Laboratory, Ltd., Tokyo Laboratory, \\ 16-2, Miyamae 1-chome, Suginami-ku, Tokyo 168, Japan \\ (Received February 20, 1995)
}

KEY WORDS Solid State / Thermal Reaction / Polycondensation / Polyester

/ Metallic Salts of 2-Bromo- $n$-butyric Acid /

We previously investigated the thermal reactions of alkali and alkaline earth methacrylates in the solid state and found that alkaline earth methacrylates gave oligomers, i.e., dimers and trimers at $200-250^{\circ} \mathrm{C}$, while alkali methacrylates produced polymers having high molecular weights $\left(38.8 \times 10^{5}-48.0 \times 10^{5}\right)$. The crystallinity of the monomeric salts influenced the products of these thermal reactions. ${ }^{1-7}$ The crystallinity of monomeric salts also affected the products in the thermal oligomerization of the metallic salts of crotonic acid. ${ }^{8,9}$ In the case of a binary mixture of sodium methacrylate and sodium crotonate and that of sodium acrylate and sodium crotonate, the crystallinity of the monomeric salts also affects the reactivity and products. ${ }^{10,11}$

In the present study, we investigated the thermal reactions of the metallic salts of 2-bromo- $n$-butyric acid (BrBA). It was expected that the thermal reaction would cause the elimination of hydrogen bromide and subsequently the vinyl polymerization of the resulting monomer. However, the thermal reactions produced polyesters and oligoesters including dimers and trimers.

\footnotetext{
${ }^{\dagger}$ To whom correspondence should be addressed.
}

\section{EXPERIMENTAL}

Anhydrous lithium (Li-BrBA), sodium (NaBrBA), potassium (K-BrBA), magnesium ( $\mathrm{Mg}-$ $\mathrm{BrBA}$ ), calcium (Ca-BrBA), barium (BaBrBA), and strontium (Sr-BrBA) 2-bromo- $n$ butyrates were used as monomers. The monomeric salts were prepared by neutralizing BrBA, obtained from Tokyo Kasei Kogyo Co., Ltd., with metal hydroxide in methanol. After the removal of methanol on a rotary evaporator, the residue was washed with ether and dried under reduced pressure at room temperature in the presence of phosphorus pentoxide.

The monomeric salt $(1.5 \mathrm{~g})$ was put into a Pyrex tube, and heated in an oil bath under reduced pressure at 110,130 , and $150^{\circ} \mathrm{C}$ for $2 \mathrm{~h}$. The reaction mixture, except that from $\mathrm{Na}-\mathrm{BrBA}$ or K-BrBA, was dissolved in water, acidified with hydrochloric acid, and then extracted with ether. The extracts were treated with diazomethane in ether. The methyl esters from $\mathrm{Sr}-\mathrm{BrBA}\left(130^{\circ} \mathrm{C}\right)$ were separated by fractional distillation under vacuum: the first fraction, $24-29^{\circ} \mathrm{C}$ at $4 \mathrm{mmHg}$; second fraction, 
$84-87^{\circ} \mathrm{C}$ at $3 \mathrm{mmHg}$; third fraction, $128-$ $135^{\circ} \mathrm{C}$ at $3 \mathrm{mmHg}$. The second fraction was purified by column chromatography (ethyl acetate $: n$-hexane $=1: 15$; silica gel (Wako Co., Ltd.) 200 mesh). The third fraction was purified again by vacuum distillation $\left(142^{\circ} \mathrm{C}\right.$ at $4 \mathrm{mmHg}$ ) followed by column chromatography (ethyl acetate: $n$-hexane $=1: 9$; silica gel 200 mesh). ${ }^{1} \mathrm{H}$ and ${ }^{13} \mathrm{C}$ NMR, IR, mass spectra of these fractions are as follows.

Second fraction (1): ${ }^{1} \mathrm{H}$ NMR $(500 \mathrm{MHz}$, $\left.\mathrm{CDCl}_{3}\right): \delta=1.021\left(\mathrm{t} ; 3 \mathrm{H},-\mathrm{CH}_{3}\right), 1.024(\mathrm{t} ; 3 \mathrm{H}$, $\left.-\mathrm{C}_{3}\right), 1.071\left(\mathrm{t} ; 3 \mathrm{H},-\mathrm{CH}_{3}\right), 1.080(\mathrm{t} ; 3 \mathrm{H}$, $\left.-\mathrm{CH}_{3}\right), 1.870-2.011\left(\mathrm{~m} ; 4 \mathrm{H},-\mathrm{CH}_{2}-\right), 2.025-$ $2.094\left(\mathrm{~m} ; 2 \mathrm{H},-\mathrm{CH}_{2}-\right), 2.143-2.215(\mathrm{~m} ; 2 \mathrm{H}$, $\left.-\underline{\mathrm{CH}}_{2}-\right), 3.757\left(\mathrm{~s} ; 3 \mathrm{H},-\mathrm{COOC} \underline{H}_{3}\right), 3.761(\mathrm{~s}$; $\left.3 \mathrm{H},-\mathrm{COOCH}_{3}\right), 4.232(\mathrm{t} ; 1 \mathrm{H}, \mathrm{CHBr}), 4.232$ (t; $1 \mathrm{H}, \mathrm{C} \underline{\mathrm{HBr}}$ ), 5.009-5.038 (m; $2 \mathrm{H}, \mathrm{C} \underline{\mathrm{HCO}}-$ $\mathrm{OCH}_{3}$ ).

${ }^{13} \mathrm{C}$ NMR $\left(125 \mathrm{MHz}, \mathrm{CDCl}_{3}\right): \quad \delta=9.51$ $\left(\mathrm{CH}_{3}\right), 11.76\left(\mathrm{CH}_{3}\right), 11.79\left(\mathrm{CH}_{3}\right), 24.45\left(\mathrm{CH}_{2}\right)$, $28.30\left(\mathrm{CH}_{2}\right), 28.52\left(\mathrm{CH}_{2}\right), 46.89(\mathrm{CHBr}), 47.27$ $(\mathrm{CHBr}), 52.32\left(\mathrm{COOCH}_{3}\right), 74.30$ ( $\underline{\mathrm{CHCOO}}-$ $\left.\mathrm{CH}_{3}\right), 74.37\left(\underline{\mathrm{CHCOOCH}}{ }_{3}\right), 169.18(\mathrm{C}=\mathrm{O})$, $169.48(\mathrm{C}=\mathrm{O}), 169.96(\mathrm{C}=\mathrm{O}), 170.05(\mathrm{C}=\mathrm{O})$.

IR ( $\mathrm{NaCl}$ neat): $2976(\mathrm{C}-\mathrm{H}), 1740(\mathrm{C}=\mathrm{O})$, 1210, $1158(\mathrm{C}-\mathrm{O}) \mathrm{cm}^{-1}$.

Mass $(\mathrm{FAB}+): m / z 269\left(\mathrm{MH}^{+}+2\right), 267$ $\left(\mathrm{MH}^{+}\right)$.

Third fraction (2): ${ }^{1} \mathrm{H}$ NMR $(500 \mathrm{MHz}$, $\left.\mathrm{CDCl}_{3}\right): \delta=0.980\left(\mathrm{t} ; 6 \mathrm{H},-\mathrm{CH}_{3}\right), 0.988(\mathrm{t} ; 6 \mathrm{H}$, $\left.-\mathrm{C}_{3}\right), 1.062\left(\mathrm{~m} ; 12 \mathrm{H},-\mathrm{C}_{3}\right), 1.087(\mathrm{t} ; 6 \mathrm{H}$,

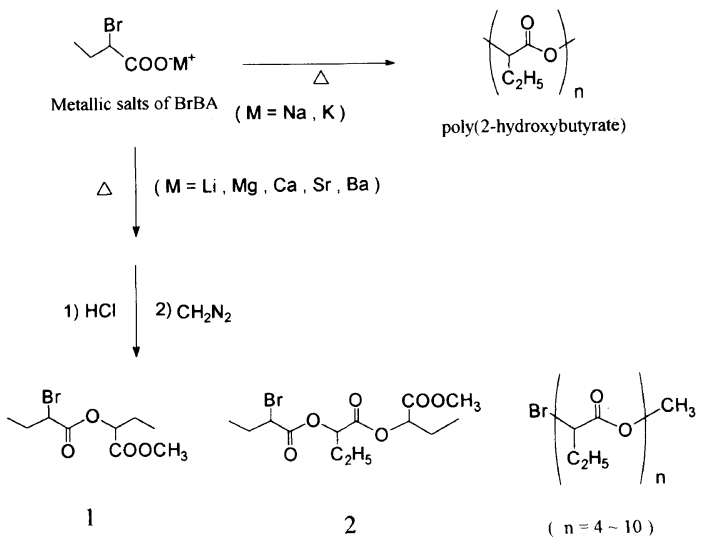

Polym. J., Vol. 27, No. 7, 1995
$\left.-\mathrm{C}_{3}\right), 1.090\left(\mathrm{t} ; 6 \mathrm{H},-\mathrm{C}_{3}\right), 1.858-2.092(\mathrm{~m}$; $\left.20 \mathrm{H},-\mathrm{CH}_{2}-\right), 2.201-2.136\left(\mathrm{~m} ; 4 \mathrm{H},-\mathrm{CH}_{2}-\right)$, $3.740\left(\mathrm{~s} ; 6 \mathrm{H},-\mathrm{OCH}_{3}\right), 3.750\left(\mathrm{~s} ; 6 \mathrm{H},-\mathrm{OCH}_{3}\right)$,

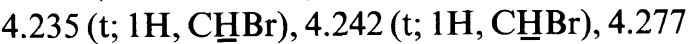
$(\mathrm{t} ; 1 \mathrm{H}, \mathrm{C} \underline{\mathrm{HBr}}), 4.288(\mathrm{t} ; 1 \mathrm{H}, \mathrm{C} \underline{\mathrm{HBr}}), 5.022-$ $5.134\left(\mathrm{~m} ; 8 \mathrm{H},-\mathrm{OC} \underline{\mathrm{H}}\left(\mathrm{C}_{2} \mathrm{H}_{5}\right) \mathrm{CO}-\right)$.

${ }^{13} \mathrm{C}$ NMR $\left(125 \mathrm{MHz}, \mathrm{CDCl}_{3}\right): \delta=9.35$ $\left(\mathrm{CH}_{3}\right), 9.50\left(\mathrm{CH}_{3}\right), 11.76\left(\mathrm{CH}_{3}\right), 11.82\left(\mathrm{CH}_{3}\right)$, $24.44\left(\mathrm{CH}_{3}\right), 24.56\left(\mathrm{CH}_{3}\right), 28.26\left(\mathrm{CH}_{2}\right), 28.42$ $\left(\mathrm{CH}_{2}\right), 28.50\left(\mathrm{CH}_{2}\right), 46.91(\mathrm{CHBr}), 46.96$ (CHBr), 47.13 (CHBr), 47.27 (CHBr), 52.27 $\left(\mathrm{COOCH}_{3}\right), 52.31\left(\mathrm{COOCH}_{3}\right), 73.86(-\mathrm{OCH}-$ $\left.\left(\mathrm{C}_{2} \mathrm{H}_{5}\right) \mathrm{CO}-\right), 74.01$ (-OCEH $\left.\left(\mathrm{C}_{2} \mathrm{H}_{5}\right) \mathrm{CO}-\right), 74.08$ $\left(-\mathrm{O} \underline{\mathrm{CH}}\left(\mathrm{C}_{2} \mathrm{H}_{5}\right) \mathrm{CO}-\right), 74.16\left(-\mathrm{O} \underline{\mathrm{CH}}\left(\mathrm{C}_{2} \mathrm{H}_{5}\right)-\right.$ $\mathrm{CO}-), 74.28\left(-\mathrm{OC} H\left(\mathrm{C}_{2} \mathrm{H}_{5}\right) \mathrm{CO}-\right), 169.07(\mathrm{C}=$ O), $169.12(\mathrm{C}=\mathrm{O}), 169.19(\mathrm{C}=\mathrm{O}), 169.26$ $(\mathrm{C}=\mathrm{O}), 169.52(\mathrm{C}=\mathrm{O}), 169.82(\mathrm{C}=\mathrm{O}), 169.98$ $(\mathrm{C}=\mathrm{O})$.

IR (KBr neat): 2980 (C-H), $1744(\mathrm{C}=\mathrm{O})$, 1242, $1156(\mathrm{C}-\mathrm{O}) \mathrm{cm}^{-1}$.

Mass (FAB +): $m / z 355\left(\mathrm{MH}^{+}+2\right), 353$ $\left(\mathrm{MH}^{+}\right), 323\left(\mathrm{M}+2-\mathrm{OCH}_{3}\right), 321(\mathrm{M}-$ $\left.\mathrm{OCH}_{3}\right), 237\left(\mathrm{M}+2-\mathrm{C}_{5} \mathrm{H}_{9} \mathrm{O}_{3}\right), 235(\mathrm{M}-$ $\left.\mathrm{C}_{5} \mathrm{H}_{9} \mathrm{O}_{3}\right), 209\left(\mathrm{M}+2-\mathrm{C}_{6} \mathrm{H}_{9} \mathrm{O}_{4}\right), 207(\mathrm{M}-$ $\mathrm{C}_{6} \mathrm{H}_{9} \mathrm{O}_{4}$ ).

HRMS: $m / z 355.0586$ (calcd for $\mathrm{C}_{13} \mathrm{H}_{22}$ $\mathrm{O}_{6}{ }^{81} \mathrm{Br} 355.0592$ ), 353.0593 (calcd for $\mathrm{C}_{13} \mathrm{H}_{22}$ $\mathrm{O}_{6}{ }^{79} \mathrm{Br} 353.0586$ ).

Oligomers of 2-hydroxybutyrate from $\mathrm{Ba}$ BrBA $\left(150^{\circ} \mathrm{C}\right):{ }^{1} \mathrm{H}$ NMR $\left(400 \mathrm{MHz}, \mathrm{CDCl}_{3}\right)$ : $\delta=0.934-1.090\left(\mathrm{~m} ; 30 \mathrm{H},-\mathrm{CH}_{3}\right), 1.857-$ $2.169\left(\mathrm{~m} ; 20 \mathrm{H},-\mathrm{C}_{2}-\right), 3.732-3.736(\mathrm{~m} ; 3 \mathrm{H}$, $\left.-\mathrm{OCH}_{3}\right), 4.232-4.250\left(\mathrm{~m} ; 1 \mathrm{H}, \mathrm{BrCH}\left(\mathrm{C}_{2} \mathrm{H}_{5}\right)-\right)$ $5.012-5.150\left(\mathrm{~m} ; 10 \mathrm{H},-\mathrm{C} \underline{\mathrm{H}}\left(\mathrm{C}_{2} \mathrm{H}_{5}\right) \mathrm{COO}-\right)$.

IR ( $\mathrm{KBr}$ neat): $2980(\mathrm{C}-\mathrm{H}), 1754(\mathrm{C}=\mathrm{O})$, 1248, $1190(\mathrm{C}-\mathrm{O}) \mathrm{cm}^{-1}$.

The reaction mixture obtained from $\mathrm{Na}$ BrBA or $\mathrm{K}-\mathrm{BrBA}$ was suspended in acetone, acidified with hydrochloric acid, and poured into water. The precipitate was filtrated with G3-glass filter, washed with water, and dried under reduced pressure. The obtained polymer was freeze-dried from benzene solution. Molecular weight was determined by gel permeation chromatography (GPC).

Poly(2-hydroxybutyrate): ${ }^{1} \mathrm{H}$ NMR (400 
$\left.\mathrm{MHz}, \quad \mathrm{CDCl}_{3}\right): \delta=0.978-1.059(\mathrm{~m} ; 3 \mathrm{H}$, $\left.-\mathrm{CH}_{3}\right), 1.950-2.041\left(\mathrm{~m} ; 2 \mathrm{H},-\mathrm{CH}_{2}-\right), 5.064$ $5.163\left(\mathrm{~m} ; 1 \mathrm{H},-\mathrm{CH}\left(\mathrm{C}_{2} \mathrm{H}_{5}\right) \mathrm{COO}-\right)$.

IR ( $\mathrm{KBr}$ neat): $2980(\mathrm{C}-\mathrm{H}), 1754(\mathrm{C}=\mathrm{O})$, 1246, $1182(\mathrm{C}-\mathrm{O}) \mathrm{cm}^{-1}$.

Anal. Calcd for $\left(\mathrm{C}_{4} \mathrm{H}_{6} \mathrm{O}_{2}\right)_{n}(86.09)_{n}$ : C, $55.81 \%$; H, $7.02 \%$. Found: C, $55.89 \% ; \mathrm{H}$, $7.05 \%$.

\section{Measurẹment}

IR spectra were recorded on a Hitachi 270-30 spectrophotometer. NMR spectra were obtained with FT-NMR spectrometer (JEOL JNM-GSX500 or GSX400). Thermogravimetry-differential thermal analyses (TG-DTA) were carried out with Mac Science TG-DTA 2000 (heating rate $10 \mathrm{Kmin}^{-1}$ in nitrogen atmosphere). GPC-measurements were performed on a Toyo Soda HLC-802UR high speed liquid chromatography using polystyrene gel columns (solvent, tetrahydrofuran; calibration, polystyrene standards). Wide angle $\mathrm{X}$ ray diffraction patterns were obtained for specimens on Rigaku Denki XG X-ray diffraction apparatus with $\mathrm{Cu}-K_{\alpha}$ radiation $(35 \mathrm{kV}$, $20 \mathrm{~mA}$ ). For gas chromatography (GC) measurements, a Hitachi 263-50 was used under the following conditions: column packing, Silicone SE-30 $(3 \mathrm{~mm} \times 2 \mathrm{~m})$; column temperature, range of $50-250^{\circ} \mathrm{C}$; heating rate, 10 $\mathrm{K} \mathrm{min}^{-1}$; carrier gas, nitrogen; gas flow, 30 $\mathrm{ml} \mathrm{min}{ }^{-1}$. The mass spectra were recorded on a JEOL JMS-HX110 mass spectrometer.

\section{RESULTS AND DISCUSSION}

TG-DTA curves of the metallic salts of BrBA showed either endothermic or exothermic peaks in the temperature range of 110 $150^{\circ} \mathrm{C}$.

The gas chromatograms of the esters obtained after acidifying the reaction mixture and subsequently converting the acids to methyl esters using diazomethane showed six peaks, the sixth being extremely broad. The first peak was that of the methyl ester of the monomer as shown by the coinjection method. Products corresponding to second and third peaks were identified by ${ }^{1} \mathrm{H} \mathrm{NMR},{ }^{13} \mathrm{C} \mathrm{NMR}$, mass, and IR spectroscopy as dimers (1) and trimers (2), respectively. The NMR spectra of the dimers suggest the presence of two diastereoisomers, the ratio of which was $1: 1$. Those of the trimers suggest the presence of at least four diastereoisomers. The other fractions had boiling points so high that they could not be separated. They were presumed to be tetramers and pentamers. The yields of the dimers, trimers, tetramers, and pentamers obtained by GC using dimethyl succinate as an internal standard are given in Table I. ${ }^{1} \mathrm{H}$ NMR and IR spectra of the sole product from Ba-BrBA $\left(150^{\circ} \mathrm{C}\right)$ indicated the formation of the oligomers of 2-hydroxybutyrate. The degree of polymerization of the oligomers, obtained from the integral ratio of the peak of the terminal methoxy group (3.732-3.736 $\mathrm{ppm})$ to that of the methylene group (1.857$2.169 \mathrm{ppm}$ ), was $c a$. 10 . The number-average molecular weight of the oligomer measured by GPC was $c a$. 800 . The yields of the oligomers could not be determined by GC since the oligomer peak showed extensive tailing. Therefore, the yield of the oligomers was calculated based on the "yield" of the recovered monomer and those of the dimers to the tetramers. It is thus demonstrated that thermal reactions of the metallic salts of BrBA in the solid state lead to condensation of the metallic salt of carboxylic acid with the bromo-group to form esters.

The products obtained from $\mathrm{Na}-\mathrm{BrBA}$ and $\mathrm{K}-\mathrm{BrBA}$ were not soluble in water, and thus were suspended in acetone, acidified with hydrochloric acid, and poured into water for precipitation. After freeze-drying from benzene solution, the molecular weights of the products as well as ${ }^{1} \mathrm{H}$ NMR and IR spectra were measured. The results of thermal reactions of Na-BrBA and K-BrBA are summarized in Table II. The number-average molecular weights of the products from $\mathrm{Na}-\mathrm{BrBA}$ were 
Thermal Polymerization in the Solid State

Table I. Thermal reactions of lithium and alkaline earth 2-bromo- $n$-butyrates in the solid state ${ }^{\text {a }}$

\begin{tabular}{|c|c|c|c|c|c|c|}
\hline \multirow{2}{*}{$\begin{array}{c}\text { Metallic salts } \\
\text { of }\end{array}$} & \multirow{2}{*}{$\begin{array}{l}\text { Heating temp } \\
\text { in }{ }^{\circ} \mathrm{C}\end{array}$} & \multicolumn{5}{|c|}{ Yield in \% } \\
\hline & & Dimer $^{b}$ & Trimer $^{\mathbf{b}}$ & Tetramer $^{\mathbf{b}}$ & Pentamer ${ }^{\mathbf{b}}$ & Oligomer $^{\mathrm{c}}$ \\
\hline \multirow{3}{*}{$\mathrm{Li}$} & 110 & n.r. ${ }^{d}$ & & & & \\
\hline & 130 & n.r. & & & & \\
\hline & 150 & 24.5 & 23.1 & 13.7 & 5.8 & 21.1 \\
\hline \multirow{3}{*}{$\mathrm{Mg}$} & 110 & n.r. & & & & \\
\hline & 130 & 8.6 & 0.6 & 1.3 & 1.5 & $-^{\mathrm{e}}$ \\
\hline & 150 & 16.3 & 0.6 & 0.2 & 0.1 & - \\
\hline \multirow{3}{*}{$\mathrm{Ca}$} & 110 & 16.4 & 0.4 & 0.2 & 0.1 & - \\
\hline & 130 & 21.2 & 6.6 & 0.9 & 0.3 & - \\
\hline & 150 & 23.4 & 17.0 & 5.4 & 1.2 & - \\
\hline \multirow{3}{*}{$\mathrm{Sr}$} & 110 & 26.1 & 16.8 & 4.3 & 1.2 & - \\
\hline & 130 & 20.7 & 25.0 & 14.9 & 7.8 & 21.7 \\
\hline & 150 & 12.6 & 18.9 & 16.9 & 13.8 & 34.1 \\
\hline \multirow{3}{*}{$\mathrm{Ba}$} & 110 & 17.3 & 24.3 & 20.1 & 15.9 & 15.3 \\
\hline & 130 & 1.6 & 4.7 & 7.8 & 10.2 & 58.8 \\
\hline & 150 & - & - & - & - & 79.9 \\
\hline
\end{tabular}

${ }^{a}$ Heating time, $2 \mathrm{~h} .{ }^{\mathbf{b}}$ Determined by gas chromatography using dimethyl succinate as internal standard. ${ }^{\mathbf{c}}$ Degree of polymerization larger than six. Calculated from the yields of the other products. ${ }^{d}$ n.r., no reaction. ${ }^{e}-$, trace.

Table II. Thermal polymerization of sodium and potassium 2-bromo- $n$-butyrates in the solid state

\begin{tabular}{|c|c|c|c|c|}
\hline \multirow{2}{*}{$\begin{array}{l}\text { Metallic } \\
\text { salts of }\end{array}$} & \multirow{2}{*}{$\begin{array}{l}\text { Heating } \\
\text { temp in } \\
{ }^{\circ} \mathrm{C}\end{array}$} & \multicolumn{3}{|c|}{ Polymer } \\
\hline & & $\begin{array}{c}\text { Yield in } \\
\%\end{array}$ & $10^{-3} \times \bar{M}_{n}^{\mathrm{b}}$ & $\bar{M}_{w} \mathbf{c} / \bar{M}_{n}$ \\
\hline \multirow{3}{*}{$\mathrm{Na}$} & 110 & 94.8 & 1.0 & 1.40 \\
\hline & 130 & 95.3 & 2.1 & 1.41 \\
\hline & 150 & 84.8 & 3.8 & 1.36 \\
\hline \multirow{3}{*}{ K } & 110 & 76.9 & 2.5 & 1.36 \\
\hline & 130 & 71.1 & 3.0 & 1.38 \\
\hline & 150 & 77.6 & 3.5 & 1.36 \\
\hline
\end{tabular}

${ }^{a}$ Heating time, $2 \mathrm{~h} .{ }^{\mathrm{b}}$ Number-average molecular weight measured by GPC. ${ }^{\mathrm{c}}$ Weight-average molecular weight measured by GPC.

$1000-3800$, and those from K-BrBA, 25003500. For from Na-BrBA and K-BrBA, the higher the heating temperature, the higher was the molecular weight of the obtained product.
The thermal reaction of $\mathrm{Na}-\mathrm{BrBA}$ proceeded almost entirely quantitatively. The spectroscopic data and elemental analysis of the polymers from Na-BrBA and from K-BrBA confirmed the formation of poly(2-hydroxybutyrate).

The yields of the dimers, trimers, tetramers, and pentamers from $\mathrm{Sr}-\mathrm{BrBA}\left(110\right.$ and $\left.130^{\circ} \mathrm{C}\right)$ are shown as functions of reaction time in Figure 1 . At $110^{\circ} \mathrm{C}$, the yields of the trimers, tetramers, and pentamers increased with time, but those of the dimers did not change after $1 \mathrm{~h}$. At $130^{\circ} \mathrm{C}$, the yields of the tetramers and pentamers increased with time, but those of the dimers increased for the initial 30 min but then decreased; the yields of the trimers also decreased after $2 \mathrm{~h}$. The yield and numberaverage molecular weight of the polymer from $\mathrm{Na}-\mathrm{BrBA}\left(130^{\circ} \mathrm{C}\right)$ are shown as functions of reaction time in Figure 2. Yield was quantitative after $30 \mathrm{~min}$. The number-average molecular weight increased with time, and reached 

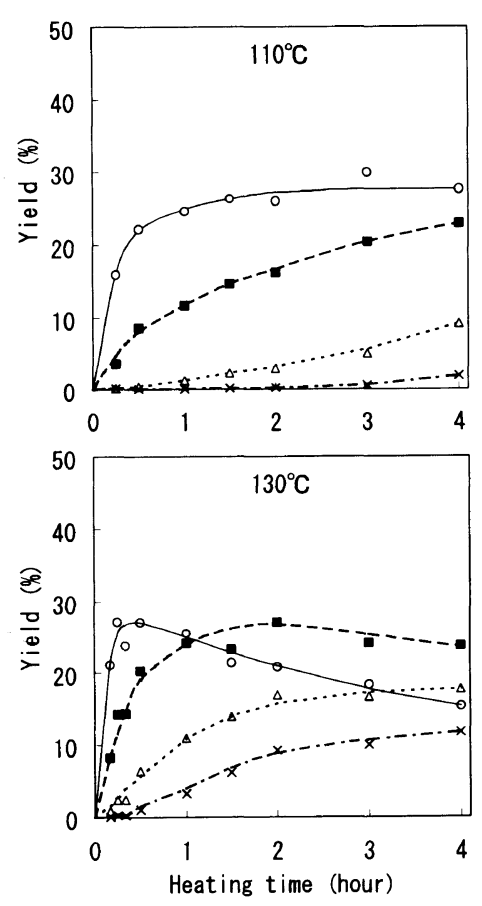

Figure 1. Thermal reactions of strontium 2-bromo- $n$ butyrate in the solid state. $O$, dimer; $\square$, trimer; $\triangle$, tetramer; $x$, pentamer.

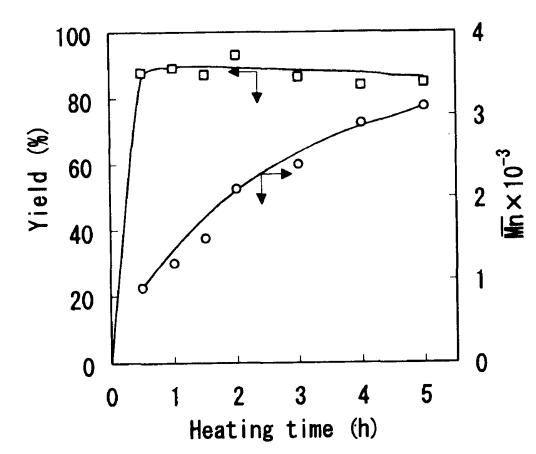

Figure 2. Thermal reactions of sodium 2-bromo- $n$ butyrate in the solid state at $130^{\circ} \mathrm{C}$.

3100 after $5 \mathrm{~h}$. These findings suggest that thermal reactions proceed in a stepwise manner.

The X-ray diffraction patterns show that $\mathrm{Li}$-, $\mathrm{Na}-$, and $\mathrm{K}-\mathrm{BrBA}$ form crystalline salts and that $\mathrm{Mg}-$, $\mathrm{Ca}-, \mathrm{Sr}-$, and Ba-BrBA form amorphous salts. Thus, the crystalline monomeric salts, except that of Li-BrBA, have high reac- tivity and the amorphous monomeric salts, low reactivity. The low reactivity of crystalline $\mathrm{Li}$ BrBA may be due to the unfavorable molecular arrangements of monomeric salts in the crystal lattice, which make it difficult for Li-BrBA to produce polyesters.

Bischoff $^{12}$ and Asahara ${ }^{13,14}$ separately reported the thermal reactions of sodium monochloroacetate and monobromoacetate in the solid state. Kozorovitskii reported the formation of poly(lactic acid) by the thermal reaction of sodium 2-chloropropanoate. ${ }^{15}$ Bezzi reported the thermal reactions of sodium 2bromopropanoate, sodium 2-bromo-2-methylpropanoate, and sodium chlorodiphenylacetate. ${ }^{16,17}$ But, no reaction mechanism or identification of the product has been reported. However, we found that the thermal reactions of alkali and alkaline earth 2-bromo- $n$ butyrates in the solid state produce polyesters in stepwise reactions and that the reactivity of the metallic salt is highly dependent on its crystallinity.

Acknowledgments. The authors thank Mr. Tadao Kuramochi of the Chemical Analysis Center, Chiba University, for carrying out the elemental analysis and recording the NMR and mass spectra.

\section{REFERENCES}

1. K. Naruchi, O. Yamamoto, M. Miura, and K. Nagakubo, Nippon Kagaku Kaishi, 1794 (1976); Chem. Abstr., 86, 120755x (1977).

2. K. Naruchi, M. Miura, and K. Nagakubo, Nippon Kagaku Kaishi, 871 (1977); Chem. Abstr., 87, 85288u (1977).

3. K. Naruchi, S. Tanaka, Y. Tamura, and M. Miura, Nippon Kagaku Kaishi, 1686 (1978); Chem. Abstr., 90, 104393e (1979).

4. K. Naruchi, S. Tanaka, and M. Miura, Nippon Kagaku Kaishi, 931 (1979); Chem. Abstr., 91, 157216b (1979).

5. K. Naruchi and M. Miura, Polymer, 22, 1716 (1981).

6. K. Naruchi, S. Tanaka, M. Higuma, M. Yamamoto, and K. Yamada, Polymer, 23, 152 (1982).

7. M. Kudoh, F. Akutsu, E. Nakaishi, T. Kobayashi, K. Naruchi, and M. Miura, Macromol. Chem., Rapid 
Commun., 15, 239 (1994)

8. K. Naruchi, S. Tanaka, M. Yamamoto, and K. Yamada, Nippon Kagaku Kaishi, 1291 (1983); Chem. Abstr., 99, 195488q (1983).

9. K. Naruchi and M. Miura, J. Chem. Soc., Perkin Trans. 2, 113 (1987).

10. M. Kudoh, K. Naruchi, F. Akutsu, and M. Miura, J. Chem. Soc., Chem. Commun., 105 (1992).

11. M. Kudoh, K. Naruchi, F. Akutsu, and M. Miura, J. Chem. Soc., Perkin Trans. 2, 555 (1993).

12. C. A. Bischoff and P. Walden, Ann., 279, 46 (1894).

13. T. Asahara, H. Okazaki, and J. Takamatsu, Kogyo
Kagaku Zasshi, 58, 999 (1955); Chem. Abstr., 50, 12813c (1956).

14. T. Asahara and S. Katayama, Kogyo Kagaku Zasshi, 67, 362 (1964); Chem. Abstr., 61, 8415a (1964).

15. A. Ya. Kozorovitskii and B. P. Manannikov, U.S.S.R. Patent, SU 852889 (1981); Chem. Abstr., 96, 35891a (1982).

16. S. Bezzi, Atti Mem. Accad. Sci., Padova, 55, 85 (1939); Chem. Abstr., 36, 5690g (1942).

17. S. Bezzi, Gazz. Chim. Ital., 79, 219 (1949); Chem. Abstr., 44, 1022e (1950). 